\title{
VARIATION IN PROTEIN AND POLYSACCHARIDE CONTENT OF \\ SERA IN THE CHRONIC DISEASES, TUBERCULOSIS, SARCOIDOSIS, AND CARCINOMA ${ }^{1}$
}

\author{
By FLORENCE B. SEIBERT, MABEL V. SEIBERT, A. JANE ATNO, AND \\ HAROLD W. CAMPBELL \\ (From the Henry Phipps Institute, University of Pennsylvania, Philadelphia)
}

(Received for publication September 3, 1946)

It is well-known that marked changes may occur in the blood proteins in many diseases, and these changes have usually been expressed as variations in the albumin to globulin $(A / G)$ ratio. In 1937, Tiselius (1) showed by means of the electrophoresis technic that at least 3 distinctly different globulins can be distinguished in serum, and later work (2) made it possible to measure them quantitatively from their electrophoretic diagrams. Furthermore, it has been shown that the relative amounts of these different protein components vary considerably in different diseases. For example, various pathological sera and plasmas were studied with this technic by Longsworth, Shedlovsky and MacInnes (3) ; pneumonia sera, by Blix (4); sarcoidosis, by Fisher and Davis (5), and also by Seibert and Nelson (6); disseminated lupus erythematosus, by Coburn and Moore (7); multiple myeloma, by Kekwick (8), and also Gutman et al (9); tuberculosis, by Seibert and Nelson (6) ; malaria, by Dole and Kendall (10); rheumatic fever, by Dole, Watson and Rothbard (11), and also by Rutstein, Clarke and Taran (12), and many other diseases.

In certain cases, extra specific serum components $(2,13)$ with mobilities different from those of the normal globulins appear. Such components have frequently been shown to be antibodies. In most cases, however, increases in the components with normal globulin mobilities occur, indicating an increase in the amount of the normal proteins or the presence of an additional substance such as another protein, lipoid (14), carbohydrate $(15,14)$, etc., having a similar mobility as, or attached to the normal protein. Thus, apparently similar changes, and therefore similar patterns, may be seen in different diseases, reflecting similar

1 Aided by a grant from the Committee on Medical Research of the National Tuberculosis Association, and also by chemical assistance from the Tuberculosis Control Division of the United States Public Health Service. physiological disturbances; but they may also, on the other hand, be due to specific causes. However, if sufficient other supporting data are available, the electrophoretic patterns may become very useful in confirming a diagnosis, and certainly are valuable in prognosis. For example, the present study shows that there can, in most cases, be a helpful differentiation between sera in cases of pulmonary tuberculosis, sarcoidosis, and carcinoma.

A number of studies have shown that an abnormal increase in lipoid occurs in the sera in certain diseases $(3,14)$, and this increase is seen in the $a$ and $\beta$ globulin components, since the lipoid has been found usually to accompany these fractions. Less attention has been paid to another important colloidal constituent of the serum; namely, polysaccharide. While its concentration is very much less than that of the serum proteins, it is present in as high or higher concentration than glucose, and may increase as much as 100 per cent or more in some cases. Lustig and Langer (16) found increases in tuberculosis, carcinoma and pneumonia. Nilsson (15) and Blix, Tiselius and Svensson (14) also found an increase in cases of pneumonia. Friedmann and Sutliff (17) noted the presence of a substance in the serum in certain diseases, probably a polysaccharide, from which the pneumococcus is capable of forming large quantities of acid.

A preliminary report was published (18) showing that a progressive increase in serum polysaccharide parallels advance in the tuberculous process. It seemed of interest, therefore, to correlate this change with the changes observed by electrophoresis in the different protein components, and thus to determine whether the increase in polysaccharide could account for any of these changes.

In this study, therefore, cases of relatively uncomplicated tuberculosis were carefully selected from the Henry Phipps Institute Clinic by one of 
us on the basis of the clinical findings, and classified as to the stage of tuberculosis. Cases of Boeck's sarcoid which were strongly suspected on the basis of the clinical examinations, or proved by biopsy, were studied. Sera from patients with carcinoma were obtained, and also 6 cases each of diabetes and of diabetes complicated with tuberculosis. Normal adult and also fetal sera were studied. All these sera were analyzed for total protein, albumin, $\alpha_{1}, \alpha_{2}, \beta$ and $\gamma$ globulins, glucose, polysaccharide, and also sedimentation rate (except the diabetics and carcinomas, which were not secured in our clinic).

\section{Clinical appraisal}

\section{METHODS}

The terms minimal, moderately advanced, and far advanced pulmonary tuberculosis are used at the Henry Phipps Institute in accordance with the definitions of the National Tuberculosis Association (19). In addition each of these classes is subdivided into 3 groups: (1) active lesions for which treatment is indicated, (2) lesions of questionable clinical significance, and (3) lesions which are apparently healed and presumably without present clinical significance.

The term "active lesions" is used in this study to indicate lesions which in x-ray appearance are soft and flocculent, or have shown recent fluctuation, and disease from which tubercle bacilli have been recently demonstrated in the sputum.

"Lesions of questionable clinical significance" include infiltrations that have an $x$-ray appearance suggesting chronicity or stability, as indicated by fibrosis and scarring in part or parts of the lesion, with softer or less well defined shadows elsewhere suggesting that the disease is in part unhealed.

"Lesions which are apparently healed and presumably without clinical significance" include disease that appears to be wholly fibrotic or fibrocalcific, and disease that shows no evidence of fluctuation on serial $x$-ray examinations.

For use in the punch card system, these lesions are given the following code numbers (which are used in the following tables).

81 active minimal pulmonary tuberculosis.

82 active moderately advanced pulmonary tuberculosis.

83 active far advanced pulmonary tuberculosis.

84 minimal pulmonary tuberculosis of questionable clinical significance.

85 moderately advanced pulmonary tuberculosis of questionable clinical significance.

In the sarcoidosis series, 4 of the cases have been verified by study of biopsy material. The diagnoses of the others were based upon the presence of extensive pulmanary fibrosis, usually with enlargement of the lymph nodes at the hilum or mediastinum, and upon the absence of significant symptoms or deterioration of health, partic- ularly in relation to the extent and density of the pulmonary shadows roentgenologically. In these cases, repeated examinations of the sputum were negative for tubercle bacilli, and the reactions to standard doses of Purified Protein Derivative were generally slight or absent. In 6 cases there were skin lesions typical of sarcoid lesions. Three of these were confirmed by consultation elsewhere. X-ray examinations of the bones of the hands and feet were not routinely made.

The diagnoses on the cases of carcinoma and diabetes were confirmed in each case in the respective institutions from which they were received. The carcinoma cases included lesions of the lungs, colon, rectum, stomach, pancreas, liver, brain, temple, tongue, breast, uterus and cervix.

Diabetic cases were studied in order to determine whether a change in the polysaccharide content of serum may be associated with the disturbed carbohydrate metabolism of this disease.

No attempt was made to obtain fasting bloods, since it had previously (20) been shown that the polysaccharide content of the serum is almost independent of the state of metabolism. The bloods were taken, allowed to clot, and within several hours the sera were removed and placed in a freezing box which kept them just at the point of freezing until the analyses could be made. It was shown (20) that under these conditions no change occurs in the polysaccharide or glucose content of serum over long periods of time.

Sedimentation. A small sample of the blood, immediately after being drawn, was mixed with oxalate and used for the sedimentation test, according to the method of Cutler (21), in the routine clinical laboratory of our institute.

Polysaccharide was determined by the carbazole reaction according to the procedure outlined recently (20), using the glucose-galactose-mannose standard. In this study, the total polysaccharide of serum was determined, and from it the glucose concentration, determined by the Somogyi (22) method, was subtracted, giving the true polysaccharide concentration.

Total protein was determined by the Kingsley (23) biuret method, using the Klett colorimeter. The calibration curve was made against serum protein determined by means of the micro Kjeldahl method.

Protein patterns were made by means of the Tiselius electrophoresis technic (1). Earlier studies $(24,6)$ using phosphate buffer, $\mathrm{pH} 7.7 \mu=0.1$, showed that a progressive rise in $\gamma$ globulin paralleled the development of tuberculosis. In addition to this change, abnormalities were noted in the form of the albumin curve, of such a nature that often there seemed to be present a component with a slightly greater mobility than the albumin. This abnormality in the albumin component does not occur if the electrophoresis is made in barbiturate buffer, but instead an extra $\alpha$ globulin appears, as first shown by Longsworth (25). It is possible, therefore, that the extra $\alpha$ globulin resolved in this latter buffer may represent the same component included in the albumin fraction in the phosphate buffer. 
All the experiments in the present study were, therefore, carried out in barbiturate buffer (veronal) $\mathrm{pH} 8.5$ to $8.6, \mu=0.1$, after the serum was dialyzed for several days against this buffer at $1^{\circ} \mathrm{C}$. and then filtered and diluted $1: 2$ with the same buffer.

In all determinations the same buffer concentration and $\mathrm{pH}$ and also the same protein concentration were used, since variation in these conditions leads to variation in the percentage of the different components $(26,27)$. In these experiments the crossed-slit arrangement of Svensson (28) was used. All electrophoreses were continued for exactly 2 hours at about 8.1 to 8.8 volts per cm., during which time the components spread throughout most of the long type cell.

Earlier reports favored using only the descending pattern for measurements, since fewer boundary errors occurred on this side, as evidenced by the smaller $e$ peak. The e peak represents a gradient due to buffer electrolyte alone, whereas the $\delta$ boundary on the ascending side is due to concentration gradients of both buffer salts and proteins.

These boundary anomalies, the $\delta$ and $\epsilon$ effects, can be greatly reduced by reducing protein concentration and also by increasing the ionic strength of the buffer $(29,26,27)$. In fact, they can be so much reduced, when a total ionic strength of 0.2 to 0.25 is used, that Svensson now recommends using the patterns on both sides, and taking an average of the results for the corresponding components on the 2 sides.

However, in the present study, since an ionic strength of 0.1 was used, calculations were made only from the descending patterns. Since relative rather than absolute values are desired, any error due to this method of calculation would have no significant bearing on the conclusions drawn. No difficulties were encountered with $\beta$ anomalies so frequently reported by many workers.

Diagrams were enlarged 5 times, and the areas due to the different components were always resolved by the same individual into curves, as described by Pedersen (30), and measured with a planimeter. Since the components are not always definitely resolved into isolated peaks, a certain amount of personal error enters into these resolutions, and Table I will show the degree of error involved under the conditions described. In some cases, the same serum was examined on 2 successive days, and in others on widely different days, even as much as 3 months apart. Different exposures during the same experiment were also compared, using different angles on the diagonal slit, in order to obtain patterns of different sizes. No systematic error seemed to be caused by such variation, but nevertheless the same angle, $30^{\circ}$, was used in all experiments in the comparative series reported in this paper. In general, as much as 2 per cent error may be expected in the globulin components, and 3 per cent in the albumin, under these conditions.

Results are reported as percentage of the total gradient area (exclusive of the $e$ component), as the different components, albumin, $\alpha_{1}, \alpha_{3}, \beta$, and $\gamma$ globulins. This method of calculation involves the least error, since no committal is made as to the composition of these com-
TABLE I

Electrophoretic measurements of same serum at different times, and with different angles at same time in veronal buffer $p H 8.5$ to $8.7, \mu=0.1$

\begin{tabular}{|c|c|c|c|c|c|c|c|c|}
\hline \multirow{2}{*}{ Name } & \multirow{2}{*}{ Date bled } & \multirow{2}{*}{ Date run } & \multicolumn{5}{|c|}{ Percentage of total protein as } & \multirow{2}{*}{ Angle } \\
\hline & & & Alb. & $\boldsymbol{\alpha}_{\mathbf{1}}$ & $\alpha_{2}$ & $\boldsymbol{\beta}$ & $\boldsymbol{\gamma}$ & \\
\hline S.F. & $1-16-45$ & $\begin{array}{l}1-23-45 \\
4-5-45\end{array}$ & $\begin{array}{l}40.1 \\
41.1\end{array}$ & $\begin{array}{l}10.8 \\
10.2\end{array}$ & $\begin{array}{l}13.7 \\
14.7\end{array}$ & $\begin{array}{l}12.7 \\
12.2\end{array}$ & $\begin{array}{l}22.8 \\
21.9\end{array}$ & $\begin{array}{l}30^{\circ} \\
30^{\circ}\end{array}$ \\
\hline M.G. & $8-17-45$ & $\begin{array}{r}8-25-45 \\
11-8-45\end{array}$ & $\begin{array}{l}29.1 \\
28.9 \\
29.3\end{array}$ & $\begin{array}{l}10.9 \\
12.2 \\
11.0\end{array}$ & $\begin{array}{l}20.6 \\
20.0 \\
20.1\end{array}$ & $\begin{array}{l}21.5 \\
21.9 \\
22.2\end{array}$ & $\begin{array}{l}18.0 \\
17.1 \\
17.5\end{array}$ & $\begin{array}{l}45^{\circ} \\
45^{\circ} \\
55^{\circ}\end{array}$ \\
\hline S.F. & $2-2-45$ & $\begin{array}{l}2-19-45 \\
4-20-45\end{array}$ & $\begin{array}{l}53.6 \\
53.4 \\
52.2 \\
50.2\end{array}$ & $\begin{array}{l}7.5 \\
8.0 \\
7.7 \\
8.6\end{array}$ & $\begin{array}{l}11.7 \\
11.8 \\
11.6 \\
11.9\end{array}$ & $\begin{array}{l}12.3 \\
12.6 \\
13.4 \\
13.4\end{array}$ & $\begin{array}{l}14.9 \\
14.2 \\
15.1 \\
15.9\end{array}$ & $\begin{array}{l}30^{\circ} \\
30^{\circ} \\
25^{\circ} \\
20^{\circ}\end{array}$ \\
\hline F.J. & 3- $7-45$ & $\begin{array}{l}3-23-45 \\
4-25-45\end{array}$ & \begin{tabular}{|}
50.0 \\
51.2
\end{tabular} & $\begin{array}{l}8.4 \\
7.1\end{array}$ & $\begin{array}{l}17.6 \\
18.0\end{array}$ & $\begin{array}{l}12.9 \\
11.3\end{array}$ & $\begin{array}{l}11.1 \\
12.5\end{array}$ & $\begin{array}{l}30^{\circ} \\
30^{\circ}\end{array}$ \\
\hline M.C. & $2-20-45$ & $\begin{array}{ll}4- & 3-45 \\
4- & 4-45\end{array}$ & $\begin{array}{l}49.1 \\
50.6\end{array}$ & $\begin{array}{l}7.5 \\
8.0\end{array}$ & $\begin{array}{r}10.3 \\
9.8\end{array}$ & \begin{tabular}{|l|}
19.1 \\
17.5
\end{tabular} & $\begin{array}{l}14.1 \\
14.1\end{array}$ & $\begin{array}{l}30^{\circ} \\
30^{\circ}\end{array}$ \\
\hline C.R. & $2-8-45$ & $\begin{array}{l}3-12-45 \\
4-27-45\end{array}$ & \begin{tabular}{|l|}
55.2 \\
52.6
\end{tabular} & $\begin{array}{l}7.3 \\
9.1\end{array}$ & $\begin{array}{l}9.5 \\
9.6\end{array}$ & \begin{tabular}{|l|}
11.6 \\
11.8
\end{tabular} & \begin{tabular}{|l|}
16.4 \\
16.9
\end{tabular} & $\begin{array}{l}30^{\circ} \\
30^{\circ}\end{array}$ \\
\hline A.F. & $2-7-45$ & $\begin{array}{l}3-14-45 \\
4-5-45\end{array}$ & \begin{tabular}{|l|}
45.9 \\
46.8 \\
\end{tabular} & $\begin{array}{l}9.9 \\
8.7\end{array}$ & \begin{tabular}{|l|}
12.0 \\
12.3
\end{tabular} & \begin{tabular}{|l|}
15.9 \\
15.4
\end{tabular} & \begin{tabular}{|l|}
16.4 \\
16.8
\end{tabular} & $\begin{array}{l}30^{\circ} \\
30^{\circ}\end{array}$ \\
\hline J.B. & $2-10-45$ & $\begin{array}{l}3-27-45 \\
3-29-45\end{array}$ & \begin{tabular}{|l|}
50.6 \\
50.0
\end{tabular} & $\begin{array}{l}8.8 \\
8.7\end{array}$ & \begin{tabular}{|l|}
14.7 \\
14.7
\end{tabular} & \begin{tabular}{|l|}
13.7 \\
14.1
\end{tabular} & $\begin{array}{l}12.2 \\
12.4\end{array}$ & $\begin{array}{l}35^{\circ} \\
35^{\circ}\end{array}$ \\
\hline S.S. & $2-5-45$ & 3- 7-45 & $\begin{array}{l}52.4 \\
51.1\end{array}$ & $\begin{array}{l}8.2 \\
8.8\end{array}$ & \begin{tabular}{|l|}
11.1 \\
11.6
\end{tabular} & \begin{tabular}{|l|}
14.7 \\
14.1
\end{tabular} & \begin{tabular}{|l|}
13.7 \\
14.3
\end{tabular} & $\begin{array}{l}30^{\circ} \\
35^{\circ}\end{array}$ \\
\hline J.G. & $1-10-44$ & $2-3-44$ & \begin{tabular}{|l|}
44.6 \\
41.1
\end{tabular} & $\begin{array}{l}6.8 \\
7.8\end{array}$ & \begin{tabular}{|l|}
12.2 \\
12.7
\end{tabular} & \begin{tabular}{|l|}
17.2 \\
18.4
\end{tabular} & \begin{tabular}{|l|}
19.4 \\
19.9 \\
\end{tabular} & $\begin{array}{l}35^{\circ} \\
45^{\circ}\end{array}$ \\
\hline S.C. & 7- $9-46$ & $7-16-46$ & \begin{tabular}{|l|}
34.3 \\
33.4
\end{tabular} & $\begin{array}{l}10.9 \\
11.5\end{array}$ & \begin{tabular}{|l|}
16.3 \\
16.1
\end{tabular} & $\begin{array}{l}14.7 \\
13.7\end{array}$ & \begin{tabular}{|l|}
23.9 \\
25.3
\end{tabular} & $\begin{array}{l}30^{\circ} \\
30^{\circ}\end{array}$ \\
\hline
\end{tabular}

ponents. It is known that a considerable percentage of some of these components is. not protein. For example, it was emphasized earlier that considerable lipoid and carbohydrate accompany the $\alpha$ and $\beta$.components. However, even these results do not give an entirely true picture for comparison, since the total protein and colloidal concentration of different sera vary. Therefore, in spite of the obvious errors involved, the method of calculating the actual grams per cent of each component from the total protein concentration, as used extensively by other workers $(31,32)$, is also used here, and the results are recorded as the second item under each component. While the actual content in grams of each component could also be calculated directly from the electrophoretic diagrams, no more accurate results would be obtained, since the refractive index increments of the various colloidal constituents necessary in the calculations are also not known.

In spite of the inherent errors indicated, the differences recorded for the different stages of disease and different diseases are so great that the conclusions drawn are, without doubt, valid. 


\section{RESULTS}

Since it is impossible to include the actual analyses of all cases, because of the large number, an attempt has been made to give summarizing tables which will contain data to show for each type of case the mean, the standard deviation, the probable error, the range, and also the significance of the deviations from the normal means.

The method of calculating this significance is as follows.

The standard deviation $(\sigma)=\sqrt{\frac{2 d^{2}}{N}}$, where $d=$ the difference from the mean, and $N=$ the number of cases studied.

$$
\text { Probable error }(E)=0.6745 \frac{\sigma}{\sqrt{N}} \text {. }
$$

$a_{1}-a_{2}=$ the difference between the mean $\left(a_{1}\right)$ of the normal group and that of the group under study $\left(a_{2}\right)$.
Probable error of $\left(a_{1}-a_{2}\right)=\sqrt{E_{1}^{2}+E^{2}}$.

The significance of the differences from the normal mean is shown by the ratio

$$
\frac{a_{1}-a_{2}}{\sqrt{{\overline{E_{1}}}^{2}+E_{2}^{2}}} \text {. }
$$

For example, if this ratio is 5 , then, according to Gavett (33), the odds against getting a mean of a similar group which is outside of the probable error are about 1,300 to 1 , and the difference is therefore highly significant. If the ratio is 3 the odds are only 22 to 1 ; if the ratio is 4 the odds are 142 to 1 ; if it is 6 the odds are 20,000 to 1 ; if it is 7 the odds are 445,000 to 1 ; etc.

Table II shows, in the top half, the number of cases studied and their means for the different analyses. The lower half gives the ratios, which show the significance of the deviations of these means from the normal. The electrophoretic data

TABLE II

\begin{tabular}{|c|c|c|c|c|c|c|c|c|c|c|c|c|c|c|}
\hline \multirow{3}{*}{ Diagnosis } & \multirow{3}{*}{$\begin{array}{l}\text { Num- } \\
\text { ber } \\
\text { cases }\end{array}$} & \multirow{3}{*}{$\mid \begin{array}{c}\begin{array}{c}\text { Poly- } \\
\text { saccha- } \\
\text { ride }\end{array} \\
\begin{array}{c}\text { mgm. } \\
\text { per } \\
\text { cent }\end{array}\end{array}$} & \multirow{3}{*}{$\begin{array}{c}\begin{array}{c}\text { Total } \\
\text { pro- } \\
\text { tein }\end{array} \\
\begin{array}{c}\text { grams } \\
\text { per } \\
\text { cent }\end{array}\end{array}$} & \multirow{2}{*}{\multicolumn{2}{|c|}{ Albumin }} & \multicolumn{8}{|c|}{ Globulins } & \multirow{3}{*}{$\begin{array}{l}\text { Albumin } \\
\text { to globu- } \\
\text { lin ratio } \\
\text { (A/G) }\end{array}$} \\
\hline & & & & & & \multicolumn{2}{|c|}{$\boldsymbol{\alpha}_{1}$} & \multicolumn{2}{|c|}{$\alpha z$} & \multicolumn{2}{|c|}{$\boldsymbol{\beta}$} & \multicolumn{2}{|c|}{$\boldsymbol{\gamma}$} & \\
\hline & & & & per cent & $\begin{array}{c}\text { Erams } \\
\text { per } \\
\text { cent }\end{array}$ & per cent & $\begin{array}{c}\text { grams } \\
\text { per } \\
\text { cent }\end{array}$ & per cent & $\begin{array}{c}\text { grams } \\
\text { per } \\
\text { cent }\end{array}$ & per cent & $\begin{array}{c}\text { grams } \\
\text { per } \\
\text { cent }\end{array}$ & per cent & $\begin{array}{c}\text { grams } \\
\text { per } \\
\text { cent }\end{array}$ & \\
\hline \multicolumn{15}{|c|}{ Means } \\
\hline 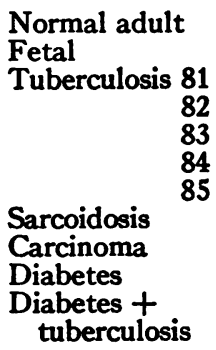 & $\begin{array}{r}43 \\
6 \\
20 \\
22 \\
26 \\
21 \\
13 \\
11 \\
23 \\
6 \\
6\end{array}$ & $\begin{array}{r}103 \\
69 \\
109 \\
136 \\
159 \\
109 \\
112 \\
128 \\
145 \\
115 \\
166\end{array}$ & $\begin{array}{l}7.29 \\
6.13 \\
7.27 \\
7.67 \\
7.63 \\
7.17 \\
7.20 \\
7.88 \\
6.66 \\
7.16 \\
6.82\end{array}$ & $\begin{array}{l}53.3 \\
49.8 \\
43.5 \\
35.2 \\
51.7 \\
49.4 \\
39.4 \\
42.0 \\
51.1 \\
30.4\end{array}$ & $\begin{array}{l}3.88 \\
3.62 \\
3.32 \\
2.69 \\
3.71 \\
3.54 \\
3.10 \\
2.80 \\
3.65 \\
2.11\end{array}$ & $\begin{array}{r}8.0 \\
7.7 \\
8.5 \\
10.3 \\
8.2 \\
8.6 \\
7.8 \\
10.0 \\
6.9 \\
10.9\end{array}$ & $\begin{array}{l}0.58 \\
\\
0.56 \\
0.64 \\
0.78 \\
0.59 \\
0.62 \\
0.61 \\
0.66 \\
0.50 \\
0.74\end{array}$ & \begin{tabular}{|l|}
10.4 \\
10.8 \\
12.2 \\
16.1 \\
11.4 \\
11.6 \\
10.8 \\
16.5 \\
11.3 \\
15.2
\end{tabular} & $\begin{array}{l}0.76 \\
0.78 \\
0.92 \\
1.21 \\
0.81 \\
0.84 \\
0.85 \\
1.09 \\
0.81 \\
1.03\end{array}$ & $\begin{array}{l}13.8 \\
13.8 \\
14.8 \\
15.6 \\
13.9 \\
15.5 \\
15.9 \\
16.3 \\
17.1 \\
19.5\end{array}$ & $\begin{array}{l}1.01 \\
1.00 \\
1.15 \\
1.19 \\
1.00 \\
1.11 \\
1.26 \\
1.09 \\
1.23 \\
1.33\end{array}$ & $\begin{array}{l}14.2 \\
17.8 \\
21.2 \\
23.0 \\
14.8 \\
14.9 \\
26.1 \\
15.3 \\
13.6 \\
24.0\end{array}$ & $\begin{array}{l}1.05 \\
1.30 \\
1.65 \\
1.76 \\
1.06 \\
1.08 \\
2.06 \\
1.03 \\
0.98 \\
1.62\end{array}$ & $\begin{array}{l}1.15 \\
1.00 \\
0.83 \\
0.56 \\
1.08 \\
0.99 \\
0.66 \\
0.74 \\
1.05 \\
0.46\end{array}$ \\
\hline
\end{tabular}

Means and their significance

$a_{1}-a_{2} / \sqrt{E_{1}^{2}+E_{2}^{2}}$ (Significance of variations from the means)

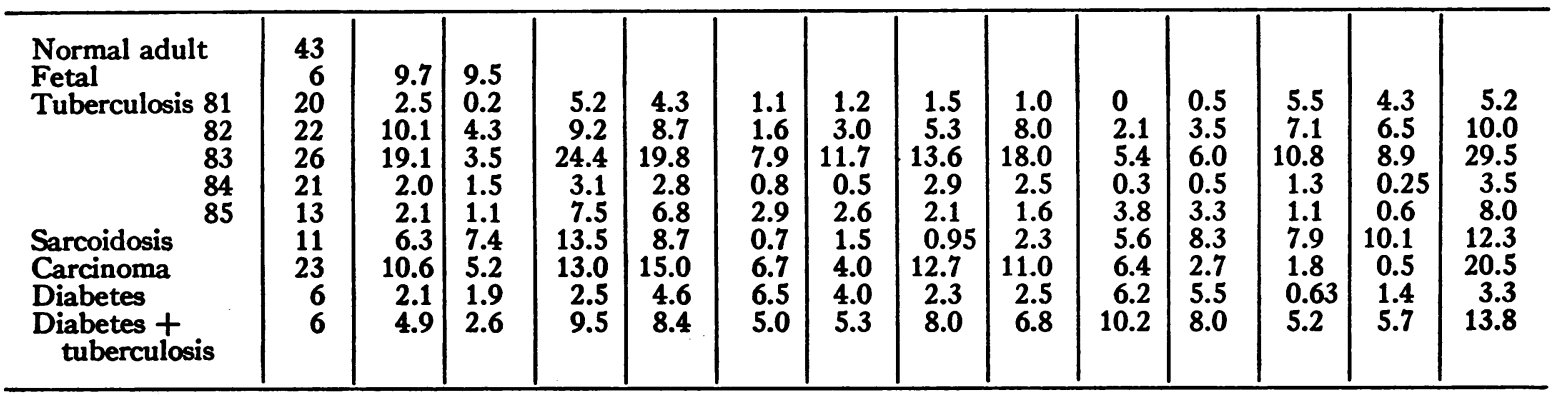


were calculated both on the basis of percentage of the total, and also as the actual grams per cent, assuming that all of the components are protein, or that the error due to the presence of non-protein substances is negligible.

Table III contains the standard deviations and probable errors corresponding to the results in Table II. Table IV contains the data,

$$
a_{1}-a_{2} \pm \sqrt{E_{1}^{2}+E_{2}^{2}},
$$

used for calculating the significance ratios, and also the ranges of the different analyses, for use in deciding what to expect from analyses on individual sera.

From these results it is readily seen that there is a significant increase in the mean total protein concentration in sarcoidosis, and a significant decrease in carcinoma, while in tuberculosis, regardless of the stage of the disease, neither an increase nor decrease is the rule.
Figure 1 shows typical electrophoretic diagrams of each type and stage of disease studied; the individual patterns were chosen because their analyses fitted most closely to the mean values for each particular type of case.

Figures 2, 3 and 4 show the individual polysaccharide concentrations plotted respectively against the $\alpha_{2}$ globulin, $\gamma$ globulin, and albumin, since it was in these components that there proved to be significant variations. In all cases the dots represent normal sera, the triangles minimal, the circles moderately advanced, the black squares far advanced tuberculosis, and the crosses carcinoma.

In minimal active tuberculosis (tuberculosis 81) a decrease in the mean $A / G$ ratio is significant, and this is obviously due to the increase in the $\gamma$ globulin, with a corresponding decrease in albumin. Therefore, the most significant change found in this early stage of the disease is the rise in the $\gamma$ globulin. As the disease progresses to the mod-

TABLE III

Standard deviations and probable errors

\begin{tabular}{|c|c|c|c|c|c|c|c|c|c|c|c|c|c|}
\hline \multirow{3}{*}{ Diagnosis } & \multirow{3}{*}{$\begin{array}{c}\begin{array}{c}\text { Poly- } \\
\text { saccha- } \\
\text { ride }\end{array} \\
\begin{array}{c}\text { mgm. } \\
\text { per } \\
\text { cent }\end{array}\end{array}$} & \multirow{3}{*}{$\begin{array}{c}\begin{array}{c}\text { Total } \\
\text { pro- } \\
\text { tein }\end{array} \\
\begin{array}{c}\text { grams } \\
\text { per } \\
\text { cent }\end{array}\end{array}$} & \multirow{2}{*}{\multicolumn{2}{|c|}{ Albumin }} & \multicolumn{8}{|c|}{ Globulins } & \multirow{3}{*}{ A/G ratio } \\
\hline & & & & & \multicolumn{2}{|c|}{$\alpha_{1}$} & \multicolumn{2}{|c|}{$\alpha_{2}$} & \multicolumn{2}{|c|}{$\boldsymbol{\beta}$} & \multicolumn{2}{|c|}{$\boldsymbol{\gamma}$} & \\
\hline & & & per cent & $\begin{array}{c}\text { grams } \\
\text { per } \\
\text { cent }\end{array}$ & per cent & $\begin{array}{c}\text { grams } \\
\text { per } \\
\text { cent }\end{array}$ & per cent & $\begin{array}{c}\text { grams } \\
\text { per } \\
\text { cent }\end{array}$ & per cent & $\begin{array}{c}\text { grams } \\
\text { per } \\
\text { cent }\end{array}$ & per cent & $\begin{array}{c}\text { grams } \\
\text { per } \\
\text { cent }\end{array}$ & \\
\hline \multicolumn{14}{|c|}{ Standard deviations } \\
\hline 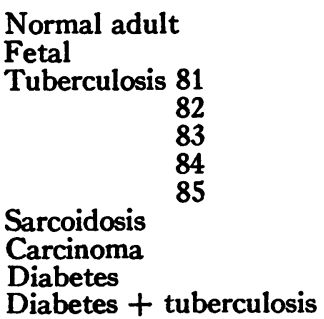 & $\begin{array}{l}14.0 \\
11.6 \\
13.2 \\
20.9 \\
18.9 \\
16.9 \\
20.1 \\
17.9 \\
25.9 \\
18.5 \\
45.8\end{array}$ & $\begin{array}{l}0.35 \\
0.42 \\
0.59 \\
0.56 \\
0.67 \\
0.48 \\
0.44 \\
0.36 \\
0.78 \\
0.23 \\
0.64\end{array}$ & $\begin{array}{l}2.6 \\
4.1 \\
7.2 \\
5.2 \\
3.1 \\
3.4 \\
4.9 \\
5.9 \\
3.0 \\
8.5\end{array}$ & $\begin{array}{l}0.23 \\
0.37 \\
0.44 \\
0.44 \\
0.34 \\
0.26 \\
0.47 \\
0.53 \\
0.17 \\
0.73\end{array}$ & $\begin{array}{l}1.35 \\
1.45 \\
1.90 \\
2.00 \\
1.40 \\
0.87 \\
1.20 \\
1.90 \\
0.86 \\
2.04\end{array}$ & $\begin{array}{l}0.10 \\
0.09 \\
0.13 \\
0.11 \\
0.10 \\
0.06 \\
0.09 \\
0.13 \\
0.06 \\
0.09\end{array}$ & $\begin{array}{l}1.38 \\
1.49 \\
2.23 \\
3.02 \\
2.10 \\
2.90 \\
2.00 \\
3.30 \\
1.30 \\
2.10\end{array}$ & $\begin{array}{l}0.10 \\
0.11 \\
0.15 \\
0.18 \\
0.14 \\
0.25 \\
0.16 \\
0.20 \\
0.08 \\
0.13\end{array}$ & $\begin{array}{l}1.89 \\
1.42 \\
3.08 \\
2.10 \\
2.10 \\
2.20 \\
1.70 \\
2.50 \\
1.80 \\
1.90\end{array}$ & $\begin{array}{l}0.14 \\
0.12 \\
0.28 \\
0.19 \\
0.15 \\
0.14 \\
0.15 \\
0.23 \\
0.14 \\
0.15\end{array}$ & $\begin{array}{l}2.68 \\
3.6 \\
6.7 \\
5.8 \\
2.4 \\
3.0 \\
7.7 \\
3.7 \\
3.4 \\
5.7\end{array}$ & $\begin{array}{l}0.22 \\
\\
0.35 \\
0.62 \\
0.60 \\
0.21 \\
0.25 \\
0.63 \\
0.32 \\
0.19 \\
0.34\end{array}$ & $\begin{array}{l}0.12 \\
0.18 \\
0.19 \\
0.12 \\
0.14 \\
0.12 \\
0.19 \\
0.17 \\
0.12 \\
0.17\end{array}$ \\
\hline
\end{tabular}

Probable errors of the means

\begin{tabular}{|c|c|c|c|c|c|c|c|c|c|c|c|c|c|}
\hline $\begin{array}{l}\text { Normal adult } \\
\text { Fetal }\end{array}$ & $\begin{array}{l}1.43 \\
3.20\end{array}$ & $\begin{array}{l}0.036 \\
0.117\end{array}$ & 0.27 & 0.024 & 0.14 & 0.01 & 0.14 & 0.01 & 0.19 & 0.01 & 0.27 & 0.023 & 0.012 \\
\hline Tuberculosis 81 & 1.98 & 0.089 & 0.61 & 0.056 & 0.22 & 0.014 & 0.22 & 0.017 & 0.21 & 0.018 & 0.59 & 0.053 & 0.03 \\
\hline 82 & 3.01 & 0.080 & 1.03 & 0.060 & 0.27 & 0.02 & 0.31 & 0.02 & 0.44 & 0.04 & 0.96 & 0.09 & 0.03 \\
\hline 83 & 2.50 & 0.090 & 0.69 & 0.060 & 0.26 & 0.014 & 0.40 & 0.02 & 0.28 & 0.03 & 0.77 & 0.08 & 0.02 \\
\hline 84 & 2.50 & 0.070 & 0.45 & 0.050 & 0.21 & 0.02 & 0.31 & 0.02 & 0.31 & 0.02 & 0.35 & 0.03 & 0.02 \\
\hline & 3.75 & 0.080 & 0.45 & 0.050 & 0.16 & 0.011 & 0.56 & 0.05 & 0.41 & 0.03 & 0.56 & 0.05 & 0.02 \\
\hline Sarcoidosis & 3.70 & 0.070 & 1.00 & 0.090 & 0.26 & 0.02 & 0.40 & 0.04 & 0.32 & 0.03 & 1.50 & 0.10 & 0.04 \\
\hline Carcinoma & 3.60 & 0.110 & 0.83 & 0.070 & 0.27 & 0.02 & 0.46 & 0.03 & 0.35 & 0.03 & 0.52 & 0.04 & 0.02 \\
\hline Diabetes & 5.20 & 0.060 & 0.84 & 0.050 & 0.24 & 0.02 & 0.37 & 0.02 & 0.50 & 0.04 & 0.91 & 0.05 & 0.03 \\
\hline Diabetes + tuberculosis & 12.80 & 0.180 & 2.40 & 0.210 & 0.57 & 0.03 & 0.59 & 0.04 & 0.53 & 0.04 & 1.60 & 0.10 & 0.05 \\
\hline
\end{tabular}




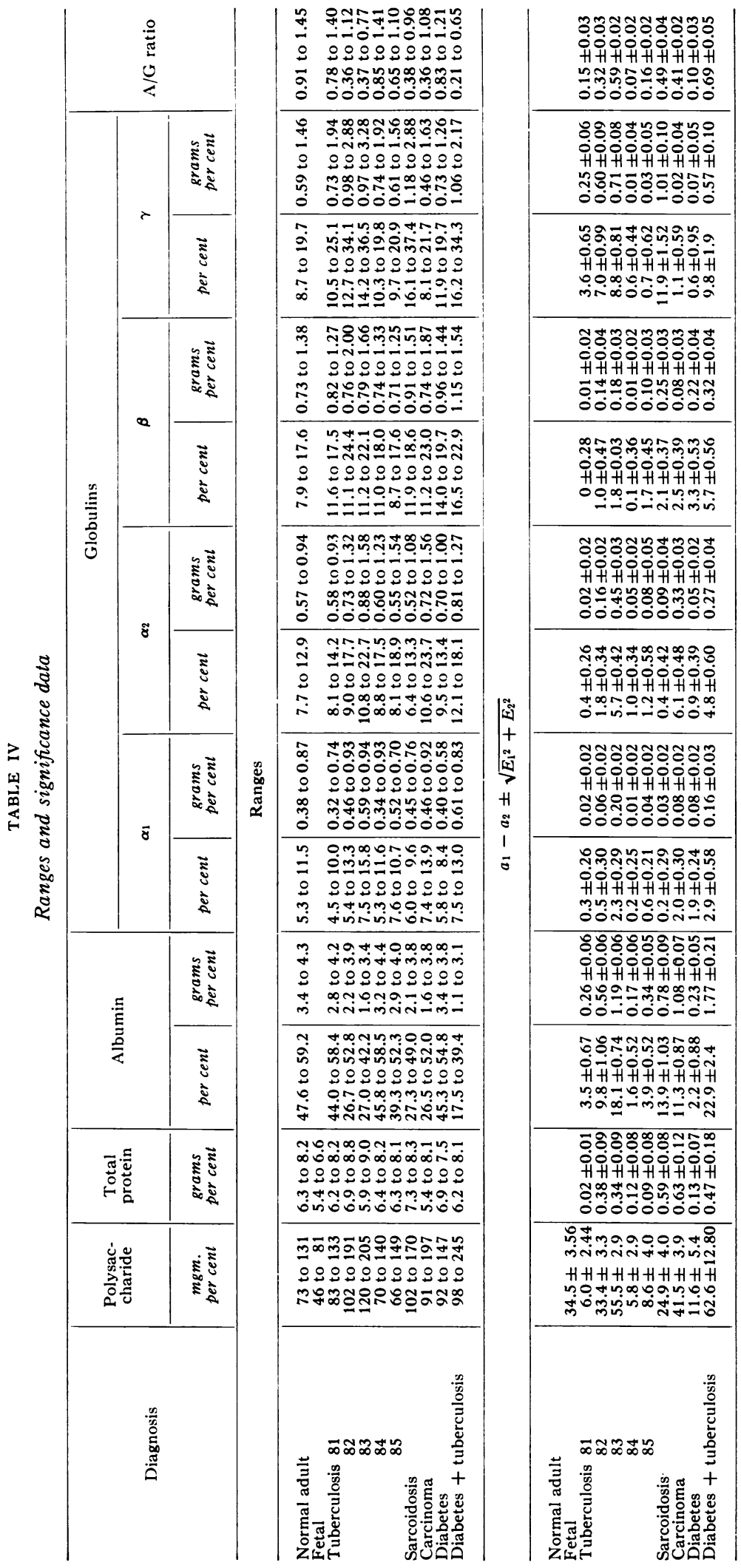




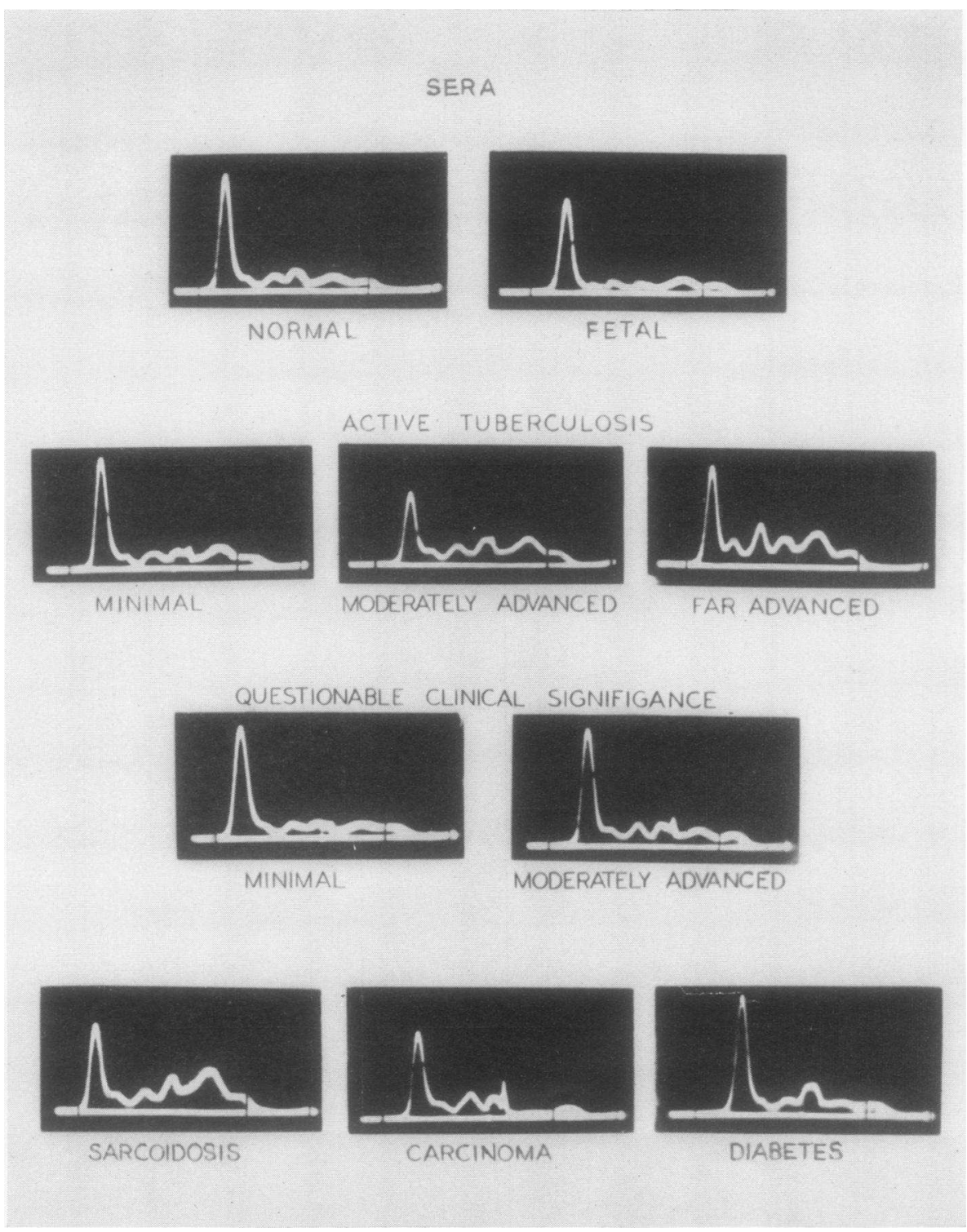

Fig. 1. Electrophoretic Diagrams of Sera Examined in Veronal Buffer pH 8.6, $\mu=0.1$, AND AT A $30^{\circ}$ A NGLE

Only descending patterns are shown. In all cases the albumin, $\alpha_{1}, \alpha_{2}, \beta$ and $\gamma$ globulin peaks and the $\epsilon$ boundary are evident.

erately advanced stage (tuberculosis 82), there appeared also a rise in the $\alpha_{2}$ globulin and polysaccharide content. With far advanced disease (tuberculosis 83) all globulins, and especially $\alpha_{2}$, as well as polysaccharide content, increased with a corresponding decrease in albumin, even though the total protein changed only slightly.

In those cases of minimal tuberculosis classified as of questionable clinical significance (tuberculosis 84 ), no deviation from the normal was found.

In cases of moderately advanced tuberculosis of questionable clinical significance (tuberculosis 85 ), the only significant change is a decrease in the albumin and the corresponding lowered $A / G$ ratio. In sarcoidosis, a large increase occurred in the mean $\gamma$ globulin, and also in the $\beta$ globulin, a 
simultaneous decrease in albumin and consequently in the $A / G$ ratio. There was also some increase in polysaccharide but by no means as much as found in cases of far advanced tuberculosis, which showed similar increases in the $\gamma$ globulin. The total protein also was always increased.

In only 4 of the 11 cases reported in this study was the diagnosis proved by biopsy. The others were strongly suspected to be sarcoidosis from the clinical data. While the number of cases is comparatively few, it is believed the conclusions are valid, since a previous group of sarcoid cases (6) yielded comparable results, and also Fisher and Davis (5) obtained similar results on a group of 12 cases of sarcoid, all of which were proved by biopsy.

Carcinoma sera showed, on the other hand, no increase in the mean $\gamma$ globulin. In fact, in the majority of cases, a very much flattened $\gamma$ peak (see Figure 1) occurred, which in further studies may be possibly resolved into a very small true $\gamma$ globulin, and another small component with mobility between the $\gamma$ and $\beta$ globulins. Several sera, especially from those cases with metastases to the liver and a resulting jaundice, showed an abnormally high $\gamma$ globulin, and these brought the average $\gamma$ up to near the normal mean. The $\alpha_{2}$ globulin, and also the polysaccharide content, in practically all cases were conspicuously increased and, of course, the albumin and $A / G$ ratio were decreased. The total protein in most cases was reduced.

The series of diabetic cases is admittedly too small to permit reliable conclusions, but it is obvious that no great change occurred, except possibly in the $\beta$ globulin. Since 5 out of the 6 cases showed a marked increase in this component, and since fat metabolism is known to be disturbed in diabetes, further study of this disease may yield helpful results.

The diabetics with advanced tuberculosis showed

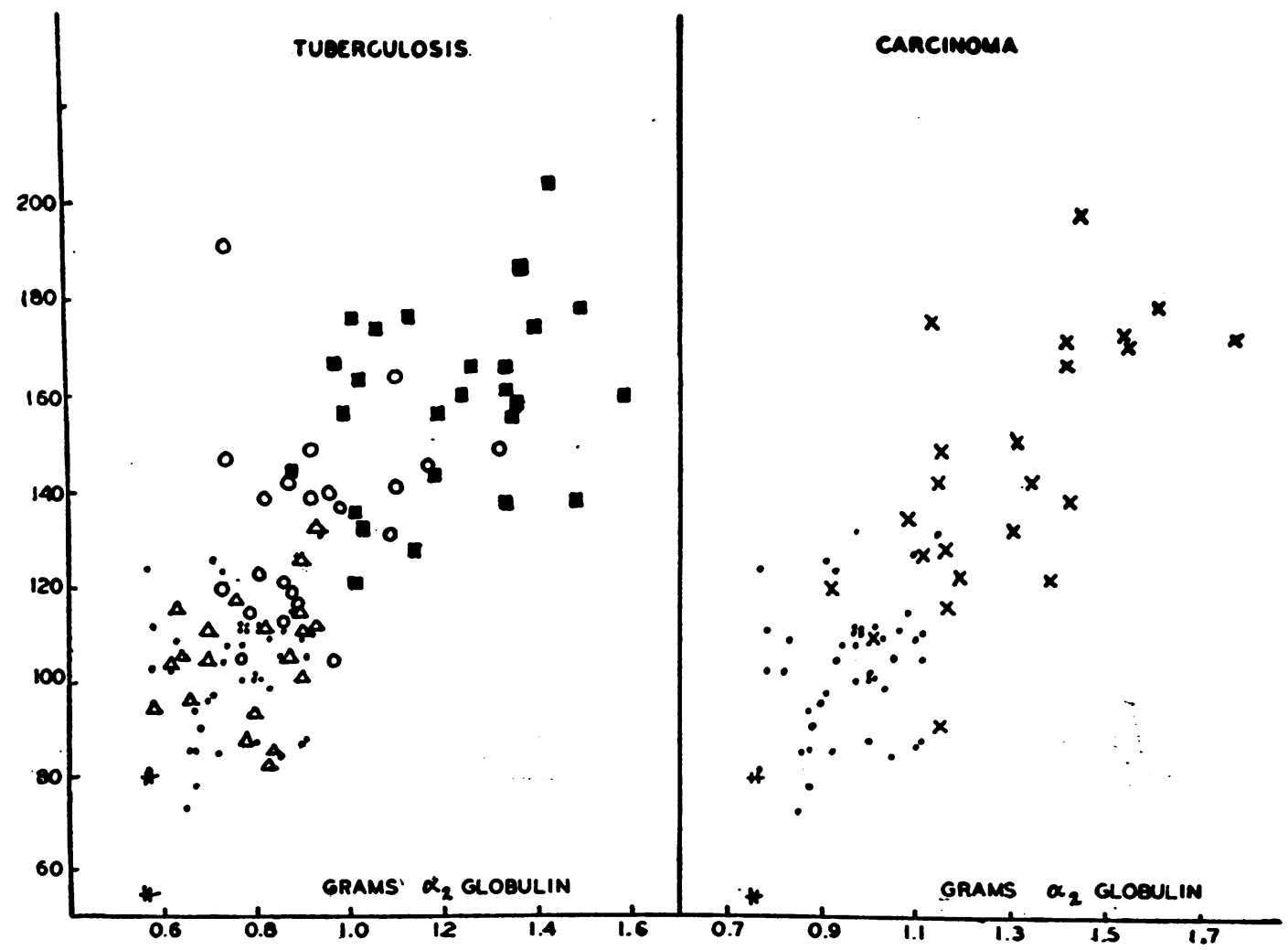

Fig. 2. Grams Per Cent $\alpha_{2}$ Globulin Are Plotted against Mgm. Per Cent Polysaccharide for Normal Adulit (•), Fetal ( $H$ ), Minimal $(\Delta)$, Moderately Advanced (O) and Far Advanced Tuberculosis $(\boldsymbol{a})$, and Carcinoma $(X)$ 


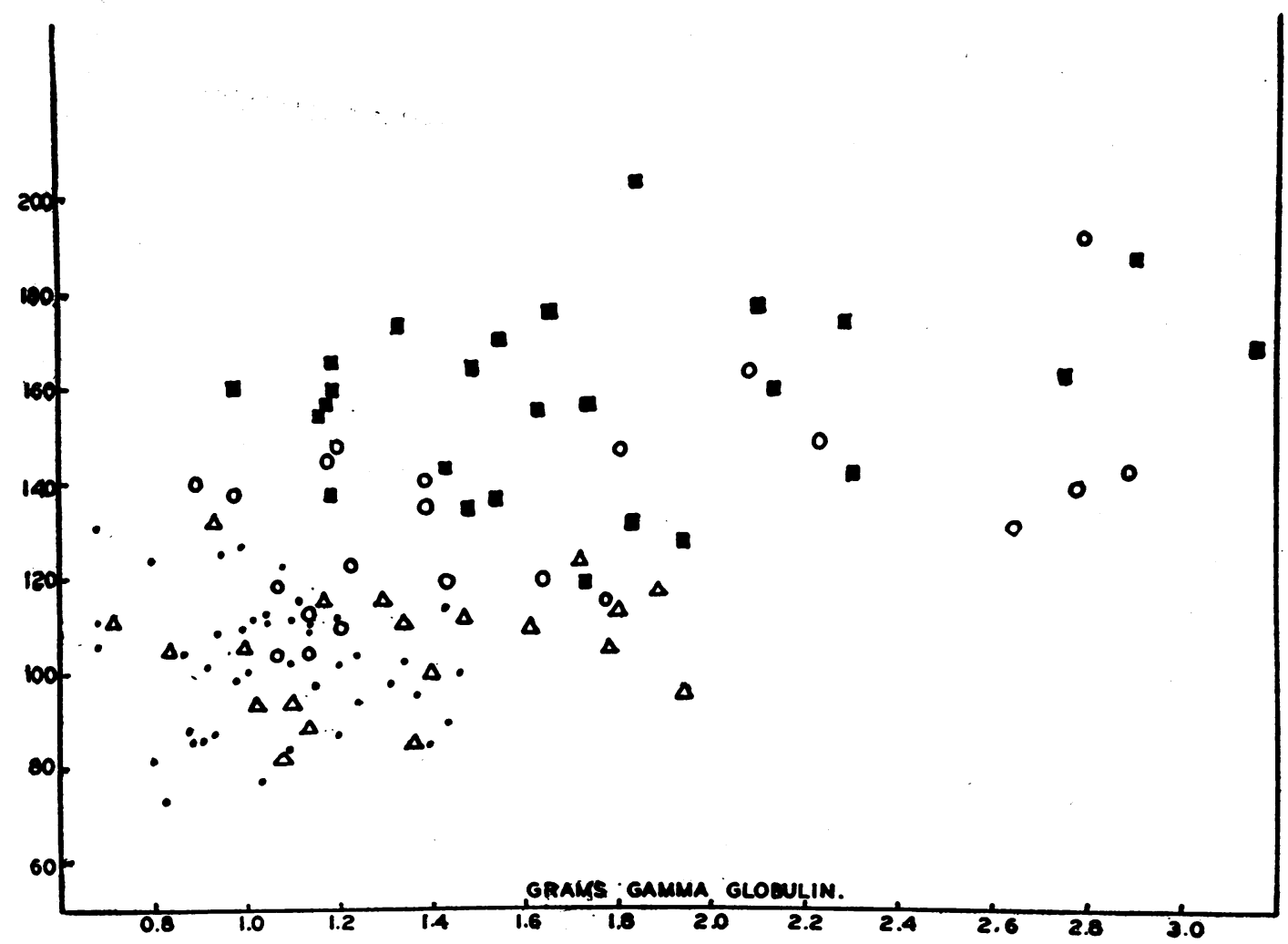

Fig. 3. Grams Per Cent $\gamma$ Globulin Are Plotted against Mgm. Per Cent Polysaccharie for Normal Adult $(\bullet)$, Mrnimal $(\Delta)$, Moderately Advanced (O) and Far Advanced Tuberculosis (घ)

changes similar to those found in the tuberculous patients, except possibly a still higher $\beta$ globulin, thus adding significance to the increase in this component noted in the non-tuberculous diabetics.

\section{Polysaccharide content of fetal serum.}

Sera taken from the cord blood of 6 patients at parturition showed a very much lowered content of polysaccharide. Even if the lowered total protein content should be taken as an index of a dilution factor, still the corrected polysaccharide content would correspond only to the lowest figures obtained in a few adults in the normal group. There is an indication, therefore, that this constituent tends to increase with age.

Only 2 electrophorectic analyses were made of fetal sera, since the results obtained corresponded well with those already reported (32). The absolute and relative concentrations of $\gamma$ globulin are higher than the adult values, and the other globulin concentrations are considerably lower, including especially the $\alpha_{2}$ globulin.

\section{Sedimentation test}

In general, with far advanced tuberculosis, the sedimentation rate was abnormal and the serum constituents were also found to be abnormal; but with less advanced disease (tuberculosis 82), 6 cases out of 20 were found to have a normal sedimentation rate, while at the same time their sera showed a considerable increase over the mean of $\gamma$ globulin and in some cases of polysaccharide. Among the group of 43 normal adults in whom no obvious clinical abnormality could be detected, 9 had sedimentation rates of 2 or more, and in all of these one of the globulins or polysaccharide, or both, was among the high range of normals. There were also 3 who had completely normal sedimentation rates, but had the highest values for polysaccharide (131, 124, $126 \mathrm{mgm}$. per cent) which were included among our normal group.

In view of the many factors which can influence the sedimentation rate, no definite correlations can be drawn on the basis of the present work. 
They do not, however, conflict with the conclusion drawn by Shedlovsky (37) that there is a correlation between the increase in $\alpha$ globulin and increase in sedimentation rate, except in our group of sarcoids where 6 cases showed an increased sedimentation rate, but no increase in $\alpha$ globulin.

\section{CONCLUSIONS AND DISCUSSION}

The data show a slight but significant rise in the mean $\gamma$ globulin component in early tuberculosis. Since antibodies for most diseases have been found in the $\gamma$ globulin fraction (34), and, furthermore, since antibodies in tuberculosis have also been found in this fraction $(35,36)$, it is reasonable to suspect that the rise in this component in the early stage of the disease process may represent an antibody reaction to the organism. It will be of interest to determine whether the rise in this component has any prognostic value in differentiating potentially dangerous cases from the self-healing type. Such a study is in progress.

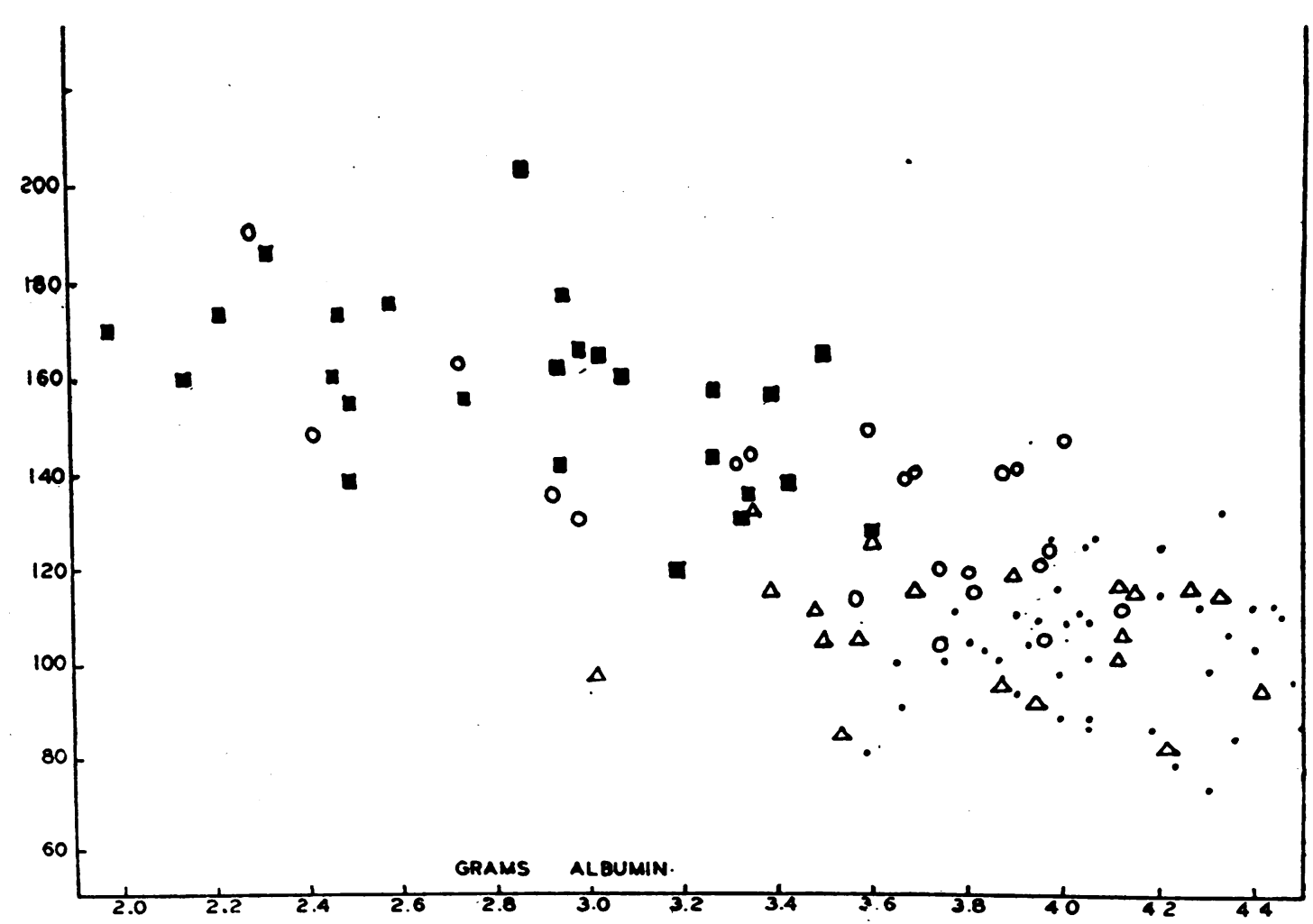

Fig. 4. Grams Per Cent Albumin Are Ploted against Mi m. Per Cent Polysaccharide for Normal Adult $(\bullet)$, Minimal $(\Delta)$, Moderately Advanced (O) and Far Advanced Tuberculosis (a)
As the disease progresses, the next change to appear is an increase in the $\alpha_{2}$ globulin and polysaccharide content of sera, and finally with far advanced disease, all of the globulins, and especially the $\alpha_{2}$ globulin, increase, with a balancing decrease in the albumin, since the total protein content does not notably change. The polysaccharide also conspicuously increases. Therefore, with advance in the disease process, it appears that the accompanying tissue destruction may be reflected by this increase in the $\alpha_{2}$ globulin and polysaccharide. It has been stated by Longsworth, Shedlovsky and MacInnes (3) that a rise in $\alpha$ globulin is found in febrile diseases. Shedlovsky and Scudder (37) concluded that a rise in $\alpha$ globulin indicated tissue destruction, and Perlmann, Glenn, and Kaufman (38) found an increase in the $\alpha$ globulin component of serum and of lymph in burns.

The argument that an increase in polysaccharide, as well as in $\alpha_{2}$ globulin, indicates the presence of tissue destruction is supported by the 
following facts. Isolated $\alpha_{2}$ globulin contains a higher percentage of polysaccharide than do the other normal serum proteins (these results will be reported in a later communication), and these 2 constituents of serum always simultaneously increase. They are both low in fetal sera and, furthermore, increase in tuberculosis as well as in carcinoma, diseases where there is known to be tissue destruction, whereas in sarcoidosis, without tissue destruction, no comparable rise in $\alpha_{2}$ globulin occurs, and, also, the rise in polysaccharide is much less. In this latter case the increase that is found in the polysaccharide is probably due to the rise in $\gamma$ globulin which also does contain some polysaccharide, but possibly of a different nature.

As cases of tuberculosis tend to heal and are then viewed as of questionable clinical significance, there is a return to the normal serum picture. If the disease has been advanced, then a decrease in the albumin still persists. In other words, the albumin is the last component to return to normal, and this is especially significant in view of the fact that Zeldis and Alling (39) found the restoration of albumin to be slower than that of the other serum proteins following acute depletion by plasmapheresis.

It is of considerable importance that 3 diseases, which frequently are difficult to differentiate clinically or from the $x$-ray picture, namely, pulmonary tuberculosis, sarcoidosis, and carcinoma, present such different analytical pictures as here described. Such analyses could, therefore, be of considerable help in diagnosis.

\section{SUMMARY}

A statistically significant rise in the $\gamma$ globulin occurs in the serum in minimal active tuberculosis, with a corresponding decrease in albumin. In moderately advanced disease, the $\alpha_{2}$ globulin and polysaccharide content also increase. These changes are still further emphasized in far advanced tuberculosis, and all the globulins are also increased. The mean total protein, however, does not differ from the normal.

No deviation from the normal occurs in minimal tuberculosis of questionable clinical significance, except possibly in a slightly lowered A/G ratio. Moderately advanced tuberculosis of questionable clinical significance shows only a decrease in albumin, indicating that it is the last component to return to normal.

Sera from cases of sarcoidosis show an increase in total protein, a proportionately large increase in $\gamma$ globulin, and only a moderate increase in polysaccharide content.

In carcinoma there is a decrease in total protein, a large increase in $\alpha_{2}$ globulin and polysaccharide content.

Fetal sera show a low total protein and polysaccharide content and low globulins, except $\gamma$ globulin, which is high.

It is suggested that the increase in $\gamma$ globulin in minimal tuberculosis may indicate antibody formation, whereas the rise in $\alpha_{2}$ globulin and simultaneous rise in polysaccharide in advanced tuberculosis and carcinoma may represent tissue destruction. Fetal sera as well as sera in sarcoidosis are characterized by high $\gamma$ globulin.

Of protein fractions isolated from normal plasma, the $\alpha_{2}$ globulin has the highest polysaccharide content. The increases in this component in the diseases studied apparently account for most of the increase in the polysaccharide of the sera. Some increase may be due also to the increase in $\gamma$ globulin, as in sarcoidosis.

We express our appreciation to Dr. Katherine R. Boucot, of the Philadelphia Tuberculosis and Health Association, for referring a number of the tuberculous patients to us.

For some of the cases of suspected sarcoid as well as the cases of diabetes complicated with tuberculosis we are indebted to Dr. S. C. Stein of the Henry Phipps Institute.

We express our sincere thanks to Dr. T. Grier Miller, Dr. Ruth Breitwiesser, Dr. Jeannette McConnell, and Dr. Cecilia Riegel of the University of Pennsylvania Hospital, and to Dr. Catherine Macfarlane of Woman's Medical College, for securing the cases and diagnoses of carcinoma.

To Dr. Frieda Baumann of Woman's Medical College we express thanks for the cases of diabetes uncomplicated with tuberculosis.

Dr. Henry Lee of Children's and Lankenau Hospitals kindly supplied us with the fetal sera.

We express our thanks to Misses Mary Mullahay and Emma DuFour for taking the blood samples and making the sedimentation determinations.

\section{BIBLIOGRAPHY}

1. Tiselius, Arne, Electrophoresis of serum globulin. II. Electrophoretic analysis of normal and immune sera. Biochem. J., 1937, 31, 1464. 
2. Tiselius, Arne, and Kabat, E. A., An electrophoretic study of immune sera and purified antibody preparations. J. Exper. Med., 1939, 69, 119.

3. Longsworth, Lewis G., Shedlovsky, T., and MacInnes, D. A., Electrophoretic patterns of normal and pathological human blood serum and plasma. J. Exper. Med., 1939, 70, 399.

4. Blix, Gunnar, Quantitative bestimmung von electrophoretisch getrennten serum globulin. Zeits. für ges. Exper. Med., 1939, 105, 595.

5. Fisher, A. M., and Davis, B. D., The serum proteins in sarcoid: electrophoretic studies. Bull. Johns Hopkins Hosp., 1942, 71, 364.

6. Seibert, F. B., and Nelson, J. W., Electrophoresis of serum. Serum proteins in tuberculosis and other chronic diseases. Am. Rev. Tuberc., 1943, 47, 66.

7. Coburn, A. F., and Moore, D. H., The plasma proteins in disseminated lupus erythematosus. Bull. Johns Hopkins Hosp., 1943, 73, 196.

8. Kekwick, R. A., The serum proteins in multiple myelomatosis. Biochem. J., 1940, 34, 1248.

9. Gutman, A. B., Moore, D. H., Gutman, E. B., McClellan, V., and Kabat, E. A., Fractionation of serum proteins in hyperproteinemia with special reference to multiple myeloma. J. Clin. Invest., 1941, 20, 765.

10. Dole, Vincent P., and Emerson, K., Jr., Electrophoretic changes in the plasma protein patterns of patients with relapsing malaria. J. Clin. Invest., 1945, 24, 644.

11. Dole, Vincent P., Watson, R. F., and Rothbard, S., Electrophoretic changes in the serum protein patterns of patients with scarlet fever and rheumatic fever. J. Clin. Invest., 1945, 24, 648.

12. Rutstein, D. D., Clarke, F. H., and Taran, L. M., Electrophoretic studies in rheumatic fever. Science, 1945, 101, 670.

13. van der Scheer, J., Lagsdin, J. B., and Wyckoff, R. W. G., Electrophoretic and ultracentrifugal analyses of antipneumococcal horse sera. J. Immunol., 1941, 41, 209.

14. Blix, G., Tiselius, A., and Svensson, H., Lipids and polysaccharides in electrophoretically separated blood serum proteins. J. Biol. Chem., 1941, 137, 485.

15. Nilsson, Ivar, Uber den glucosamingehalt des blutserums bei gesunden und pneumoniekranken. Biochem. Z., 1937, 291, 254.

16. Lustig, B., and Langer, A., Uber die Bestimmung und den Gehalt an freiem, Eiweiss- und gebundenem Nichteiweisszucker in normalen und pathologischen Serum, Liquor und Harn. Biochem. Z., 1931, 242, 320.

Lustig, B., and Nassau, E., The carbohydrate content of the proteins in blood serum, cantharidin blisters and pleural effusions. Am. Rev. Tuberc., 1941, 43, 817.

17. Friedmann, T. E., and Sutliff, W. D., Appearance of fermentable polysaccharide in the blood and a simple method of its detection. Science, 1939, 90, 335.
18. Seibert, F. B., Nelson, J. W., and Seibert, M. V., Correlation of extent of tuberculosis with amount of polysaccharide in the serum. Proc. Soc. Exper. Biol. and Med., 1943, 52, 219.

19. National Tuberculosis Association, Diagnostic Standards and Classification of Tuberculosis, 1940 Edition, New York City.

20. Seibert, F. B., and Atno, J., Determination of polysaccharide in serum. J. Biol. Chem., 1946, 163, 511.

21. Cutler, J. W., Standardization of sedimentation rate. Am. Rev. Tuberc., 1943, 48, 314.

22. Somogyi, M., A reagent for the copper-iodometric determination of very small amounts of sugar. J. Biol. Chem., 1937, 117, 771.

23. Kingsley, G. R., The direct biuret method for the determination of serum proteins as applied to photoelectric and visual colorimetry. J. Lab. and Clin. Med., 1942, 27, 840.

24. Seibert, F. B., and Nelson, J. W., Electrophoretic study of the blood protein response in tuberculosis. J. Biol. Chem., 1942, 143, 29.

25. Longsworth, L. G., Recent advances in the study of proteins by electrophoresis. Chem. Rev., 1942, 30, 323.

26. Perlmann, G. E., and Kaufman, D., The effect of ionic strength and protein concentration in the electrophoretic analysis of human plasma. J. Am. Chem. Soc., 1945, 67, 638.

27. Svensson, Harry, Electrophoresis by the Moving Boundary Method. A theoretical and experimental study. Arkiv. for Kemi, Mineralogi och Geologi, 1946, 22A, No. 10 (Thesis).

28. Svensson, H., Direkte photographische Aufnahme von Elektrophorese-Diagrammen. Kolloid.-Z.; 1939, 87, 181. Theorie der Beobachtungsmethode der gekreuzten Spalte. Kolloid.-Z., 1940, 90, 141.

29. Longsworth, L. G., and MacInnes, D. A., Electrophoresis of proteins by the Tiselius method. Chem. Rev., 1939, 24, 271.

30. Svedberg, T., and Pedersen, K. O., The Ultracentrifuge, p. 296. Oxford University Press, London, 1940.

31. Dole, Vincent P., The electrophoretic patterns of normal plasma. J. Clin. Invest., 1945, 23, 708.

32. Longsworth, L. G., Curtis, R. M., and Pembroke, R. H., Jr., The electrophoretic analysis of material and fetal plasmas and sera. J. Clin. Invest., 1945, $24,46$.

33. Gavett, G. I., A First Course in Statistical Method, p. 188. McGraw-Hill Book Co., Inc., New York, 1937.

34. Enders, J. F., The concentration of certain antibodies in globulin fractions derived from human blood plasma. J. Clin. Invest., 1944, 23, 510.

35. Seibert, F. B., and Nelson, J. W., Proteins of tuberculin. J. Am. Chem. Soc., 1943, 65, 272.

36. Emmart, E. W., and Seibert, F. B., The effect of tuberculous and sensitized sera and serum fractions on the development of tubercles in the chorio- 
allantoic membrane of the chick. J. Immunol, 1945, 50, 143.

37. Shedlovsky, T., and Scudder, J., A comparison of erythrocyte sedimentation rates and electrophoretic patterns of normal and pathological human blood. J. Exper. Med., 1942, 75, 119.

38. Perlmann, G. E., Glenn, W. W. L., and Kaufman, D.,
Changes in the electrophoretic pattern in lymph and serum in experimental burns. J. Clin. Invest., 1943, 22, 627.

39. Zeldis, L. J., and Alling, E. L., Plasma protein metabolism-electrophoretic studies. Restoration of circulating proteins following acute, depletion by plasmapheresis. J. Exper. Med., 1945, 81, 515. 